Primljen / Received: 27.12.2011. Ispravljen / Corrected: 22.2.2012.

Prihvaćen / Accepted: 12.3.2012. Dostupno online / Available online: 25.4.2012.

\section{Multicriteria decision-making in railway route planning and design}

Authors:

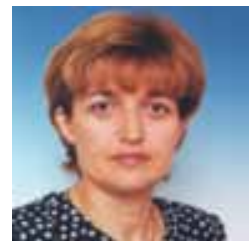

M.Sc. Milana Kosijer University of Belgrad

Faculty of Transport and Traffic Engineering m.kosijer@sf.bg.ac.rs

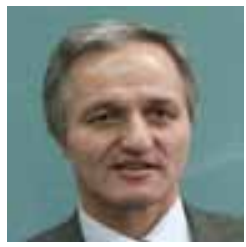

Prof. Miloš Ivić, Ph.D.

University of Belgrad

Faculty of Transport and Traffic Engineering m.ivic@sf.bg.ac.rs

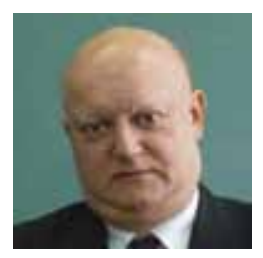

Prof. Milan Marković, Ph.D.

University of Belgrad

Faculty of Transport and Traffic Engineering milan@sf.bg.ac.rs

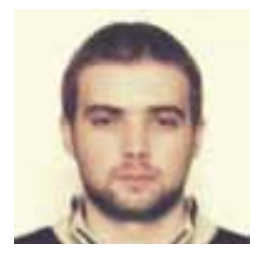

Ivan Belošević

University of Belgrad

Faculty of Transport and Traffic Engineering i.belosevic@sf.bg.ac.rs

\section{Milana Kosijer, Miloš Ivić, Milan Marković, Ivan Belošević}

Subject review

\section{Multicriteria decision-making in railway route planning and design}

The route selection methodology, based on multicriteria decision-making and applied in railway route planning and design, is presented in the paper. The proposed methodology enables an integrated and systematic resolution of this problem, and it results in the most favourable route proposal based on predefined criteria and real-life constraints. The technology is based on the compromise ranking method (VIKOR), and it has been checked during selection of one out of four railway route alternatives on the Corridor $X$, between Inđija and Novi Sad train stations.

\section{Key words:}

planning and design, railway route, best alternative selection, multicriteria decision-making, VIKOR method

Pregledni rad

\section{Milana Kosijer, Miloš Ivić, Milan Marković, Ivan Belošević}

\section{Višekriterijsko odlučivanje u planiranju i projektiranju trase željezničke pruge}

U radu je prikazana metodologija izbora trase u procesu planiranja i projektiranja željezničke pruge koja se temelji na metodama višekriterijskog odlučivanja. Predložena metodologija omogućava cjelovito i sustavno rješavanje ovog problema, čiji krajnji rezultat je prijedlog najpovoljnije trase u skladu s usvojenim kriterijima i realnim ograničenjima. Razvijena metodologija je bazirana na metodi kompromisnog rangiranja (VIKOR), a njena verifikacija provedena je na primjeru izbora jedne od četiri varijante trase željezničke pruge na dionici Koridora X, između stanica Inđija i Novi Sad.

Ključne riječi:

planiranje i projektiranje, trasa željezničke pruge, izbor najpovoljnije varijante, višekriterijsko odlučivanje, metoda VIKOR

Milana Kosijer, Miloš Ivić, Milan Marković, Ivan Belošević

\section{Multikriterien-Beschlussfassung in der Planung und Projektierung der Eisenbahntrasse}

In der Arbeit ist die Methodologie der Trassenauswahl in dem Planungs-und Projektierungsprozess einer Eisenbahngleise, die auf den Methoden der MultikriterienBeschlussfassung beruht dargestellt. Die vorgeschlagene Methodologie ermöglicht eine ganzheitliche und systematische Lösung dieses Problems, deren Endresultat der Vorschlag der günstigsten Trasse in Einklang mit den angenommenen Kriterien und realen Beschränkungen ist. Die entwickelte Methodologie basiert auf der Methode der Kompromissklassifizierung (VIKOR). Ihre Verifizierung wurde an dem Beispiel der Auswahl einer von vier Trassenvarianten der Eisenbahngleise auf der Strecke des Korridors X, zwischen den Stationen Inđija und Novi Sad durchgeführt.

\section{Schlüsselwörter:}

Planung und Projektierung, Eisenbahntrasse, Auswahl der günstigsten Variante, Multikriterien-Beschlussfassung, VIKOR-Methode. 


\section{Introduction}

Each modern railway line is a complex system that has to fulfil a number of objectives, some of which are: sufficient capacity, appropriate speed of travel, comfortable transport, high level of traffic safety, economic viability, blending in with the existing and planned developments, and environmental protection. Some objectives call for implementation of maximum values (capacity, safety, quality of transport), while other require minimum values (investment in construction, operation costs, time of travel, influence on and consequences for physical setting and living environment). In addition, some can be expressed in quantitative - monetary units (investments, costs), and some through indicators of non-monetary nature (time of travel, capacity, safety). Some objectives can even be described qualitatively through descriptive grades or points (noise, air and water pollution, occupation of land, accessibility, preservation of cultural, historic and natural heritage, influence on flora, fauna, climate, landscape, etc.). The fulfilment of these objectives points to the need to develop and propose, for the planning and realization of new or upgrade of existing railway lines, a new methodology for the evaluation and decision-making in the design of such facilities. The newly proposed methodology assumes implementation of a systematic approach and an iterative optimisation process. As railway lines belong to the group of discrete systems, this complex and multidimensional optimization process will be realized through the following activities:

- establishment of a set of realistic alternative route solutions,

- evaluation of these alternative solutions based on appropriate criteria,

- ranking of alternative solutions,

- analysis and selection of the most favourable alternative solution.

In the newly proposed process, the set of realistic alternative route solutions is generated by varying basic technical elements of the route, and by adjusting solutions to the existing physical setting, terrain and geological and hydrological conditions. The evaluation criteria are defined based on objectives that have been established in advance. The evaluation results in a ranking list which enables selection of either one alternative solution (as a final solution) or several alternative solutions (short listing) that meet the criteria taking into account realistic limitations. In this process, the decision making must be objective and documented, or as objective as possible. Although the full objectivity can never be reached, highly objective decisions can be made using the multicriteria decision-making method, i.e. the discrete decision-making method, as related to single-criteria and one-dimensional methods.

Since there are several alternative railway route solutions and several criteria for their evaluation, some of which must be maximised and some minimised, and as all of them are incomparable to each other because of incompatibility of measurement units, it is quite obvious that decisions will be made under conflicting conditions. This very fact shows that such problems must be solved using multicriteria decisionmaking principles in conjunction with some of the methods that have been developed for the resolution of such highly complex problems. In the light of the above considerations, the MCCR method (multicriteria compromise ranking) has been adopted in this paper.

To enable successful application of this method, the following criteria have been adopted in this paper: investments for route construction, route operation and maintenance costs, capacity of the route, effects the route has on physical development, and influence of the route on living environment. As to relative weights, i.e. weight coefficients, showing significance and importance of each criterion adopted in the study, these weights have been defined in such a way that they have several value combinations or scenarios that enable us to verify stability of the solution.

The applicability of the newly proposed and developed methodology for multicriteria decision-making has been verified by selecting one out of four alternatives (Čortanovci, Maradik, Kombinovana, Kovilj) of the new double-track railway route situated on the Corridor $X$, at the Indija - Novi Sad section. The results obtained confirm the adequacy and practical applicability of this methodology for the resolution of this problem.

\section{Methodology for railway route planning and design}

Analyses related to railway infrastructure facilities realized in the past have often lead to investment mistakes and were the cause of negative impacts on living environments, both during realization and use of these facilities. Several reasons have provoked such occurrences, and one of them is related to the deficiencies in the methodologies used in the planning and design of such railway infrastructure. These methodologies were based on methods in the scope of which possible alternatives were compared using a single financial/economic criterion (planned investments and costs), i.e. without full recognition and evaluation of other possible aspects [9]. In the scope of these methodologies, the decisionmaking on the selection of the most appropriate solution, was in most cases subjective and experience based, and the results and the final decision was insufficiently documented/justified. That is why the above mentioned consequences of this approach were unavoidable and evident.

In order to find long-term solutions in the sense of increasing the quality of transport services in railway transport, preserving the quality of living environments, and ensuring rational use of all natural resources, it has become obvious that more complex and comprehensive methodological procedures and methods should be developed and used for proper evaluation and assessment of railway infrastructure facilities at the stage of their planning 
and design. This has resulted in the development of the new methodology presented in the paper. In this methodology, it is assumed that the technical-technological, transport, spatial and environmental criteria should be used, in addition to financialeconomic criteria, in the process of planning and design of new railway lines, or during renovation of existing lines. In addition, multicriteria decision-making methods should be applied in the selection of the most favourable solution. Thus all circumstances and aspects that are likely to influence the final decision making are taken into account through combined analysis of all these criteria. At that, multicriteria decision-making methods show greater objectivity when compared to traditional single-criterion based methods at the stage when the most favourable solution needs to be defined. In this way, the existing methodologies are improved and extended, and users are provided with the possibility to select methods according to their own preferences, taking care that solutions selected are the right and bestpossible ones $[1,2,5,10,19,21]$.

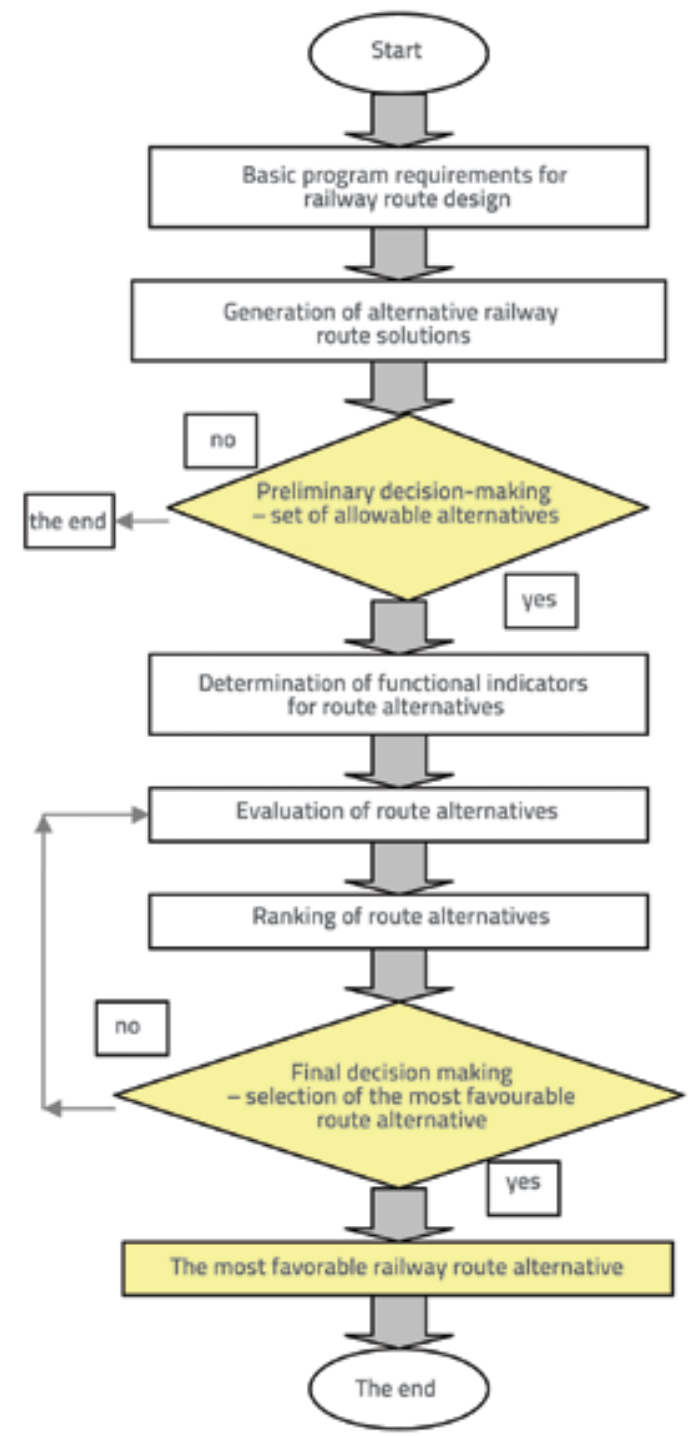

Figure 1. Iterative optimisation process for railway route design
This methodology assumes implementation of a systematic approach and an iterative optimisation process that is realized through several typical levels, as shown in Figure 1. This particular process is implemented because railway lines belong to the group of discrete systems that can not be described through a comprehensive mathematical model, but rather through generation of alternative railway route solutions. Thus, once the general objective and the list of criteria are set, this process involves, first, the preliminary decision-making (ranking and selection of allowable alternative solutions) and then the final decision-making (selection of the most favourable solution). From the mathematical standpoint, this means that extreme values must be defined for the selected objective, i.e. for criteria and for appropriate criterial functions. This is a complex process that calls for a number of iterations, at various stages and levels.

Once basic program requirements for design work are defined (limit values for horizontal and vertical elements of the route, structural elements of the route, traction system and transport organisation scheme, and a synthesis map of routerelated limitations), the process continues with the generation and elaboration of possible route alternatives. This activity starts from the basic objective and use of the railway system, which stays the same for all alternative solutions, i.e. only the values of specific system parameters are modified: $x_{1^{\prime}} x_{2^{\prime}}, x_{m^{\prime}}$ which form the vector $\mathbf{x}$. One combination of the vector $\mathbf{x}$ is in fact one alternative solution $V_{j}$;

$V_{j}=\left(x_{1 j}, x_{2 j}, \ldots, x_{n j}\right)$

where:

$V_{j}$ - j-th alternative solution, while

$x_{i j}$-is the value of the $i$-th parameter for the $j$-th alternative solution.

Parameters for the generation of alternative solutions are:

$x_{1}$ - railway line category

$x_{2}$ - design speed

$x_{3}$ - horizontal and vertical geometric elements

$x_{4}$ - cross sectional elements

$x_{5}$ - physical disposition of the route

$x_{6}$-technical equipment level

$x_{7}$ - traffic operation system.

Alternative solutions for complex systems such as railways can not be generated by an automated procedure or model. In other words, no single technical, mathematical and computerbased procedure or rule can replace the designer's creativity in the generation of alternative solutions. Just as every railway line has unrepeatable conditions with regard to its circumstances and setting, the alternative solutions formed can also be considered as unique.

Each solution has to be tested in order to determine whether or not it is allowable. This is why the preliminary decisionmaking process is conducted. Its aim is to eliminate solutions 
whose parameters do not meet limitations that have been set in advance. Once functional values are defined for each allowable alternative, the procedure continues by evaluation of allowable solutions. Having in mind the predefined objective, each alternative solution is evaluated and assessed in a documented manner, based on a list of criteria. The evaluation of alternative solutions is followed by their ranking so that the order of precedence, i.e. the ranking list, can be established. If there are several combinations of weight coefficients, i.e. if there are several scenarios, then an appropriate ranking list is established for each scenario. The ranking lists with alternative route solutions are used in the final decision making, i.e. in the selection of one (final) alternative solution or several alternative solutions (short listed solutions). Such an approach and order of activities defined in this methodology enables an objective and sufficiently documented decisionmaking as well as the final decision-making about the most favourable railway route solution, based on an acceptable minimum level of subjective assessments, and a well supported explanation of all results.

\section{Mathematical formulation of the multicriteria decision-making methodology}

Making design decisions about the most favourable railway route alternative is a complex process which belongs to the category of multicriteria decision-making, because decisions are made under conflicting conditions, which is the result of:

- existence of a set formed of several alternative solutions,

- existence of several criteria with different measurement units,

- existence of opposition and conflicts between the criteria.

The methodology involving multicriteria decision-making in the selection of railway route alternatives is a discrete system characterized by the $m x n$ type decision-making matrix, i.e. by the matrix with $m$-number of alternative solutions, and $n$-number of criteria ( $m \geq 2$ and $n \geq 2$ ), as shown in Table 1 .

Table 1. Multicriteria decision-making matrix

\begin{tabular}{|c|c|c|c|c|c|c|c|}
\hline \multicolumn{8}{|c|}{ Criteria } \\
\hline \multirow{9}{*}{ 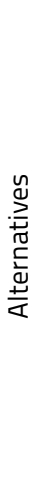 } & & $K_{1}$ & $K_{2}$ & $\ldots$ & $K_{i}$ & $\ldots$ & $K_{n}$ \\
\hline & $V_{1}$ & $f_{11}$ & $f_{12}$ & $\ldots$ & $f_{1 i}$ & $\ldots$ & $f_{1 n}$ \\
\hline & $V_{2}$ & $f_{21}$ & $f_{22}$ & $\ldots$ & $f_{2 i}$ & $\ldots$ & $f_{2 n}$ \\
\hline & $\ldots$ & $\cdots$ & $\ldots$ & $\ldots$ & $\ldots$ & $\ldots$ & $\ldots$ \\
\hline & $V_{j}$ & $f_{j 1}$ & $f_{j 2}$ & $\ldots$ & $f_{j i}$ & $\ldots$ & $f_{j n}$ \\
\hline & $\ldots$ & $\ldots$ & 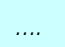 & $\ldots$ & $\ldots$ & $\ldots$ & $\ldots$ \\
\hline & $V_{m}$ & $f_{m 1}$ & $f_{m 2}$ & $\ldots$ & $f_{m i}$ & $\ldots$ & $f_{m n}$ \\
\hline & & $\omega_{1}$ & $\omega_{2}$ & $\ldots$. & $\omega_{i}$ & $\ldots$ & $\omega_{n}$ \\
\hline & & $\max$ & $\min$ & $\ldots$ & $\max$ & $\ldots$ & $\min$ \\
\hline
\end{tabular}

where:

$V_{j}\left(V_{1}, V_{2}, \ldots V_{m}\right)$ - possible alternative route solutions

$K_{i}\left(K_{1}, K_{2}, \ldots K_{n}\right)$ - evaluation criteria selected

$f_{i j}\left(f_{11}, f_{12}, \ldots f_{m n}\right)$ - value of the $i$-th criterial function for the $j$-th alternative solution

$\omega_{i}\left(\omega_{1}, \omega_{2}, \ldots, \omega_{n}\right) \quad$ - weight coefficients for individual decision-making criteria

maxili min - typical criterial functions.

\subsection{Criteria and evaluation of alternative solutions}

A previously formed set of allowable route alternatives is assumed in the methodology for making decisions about selection of railway routes. The methodology involves several steps, cf. Figure 2.

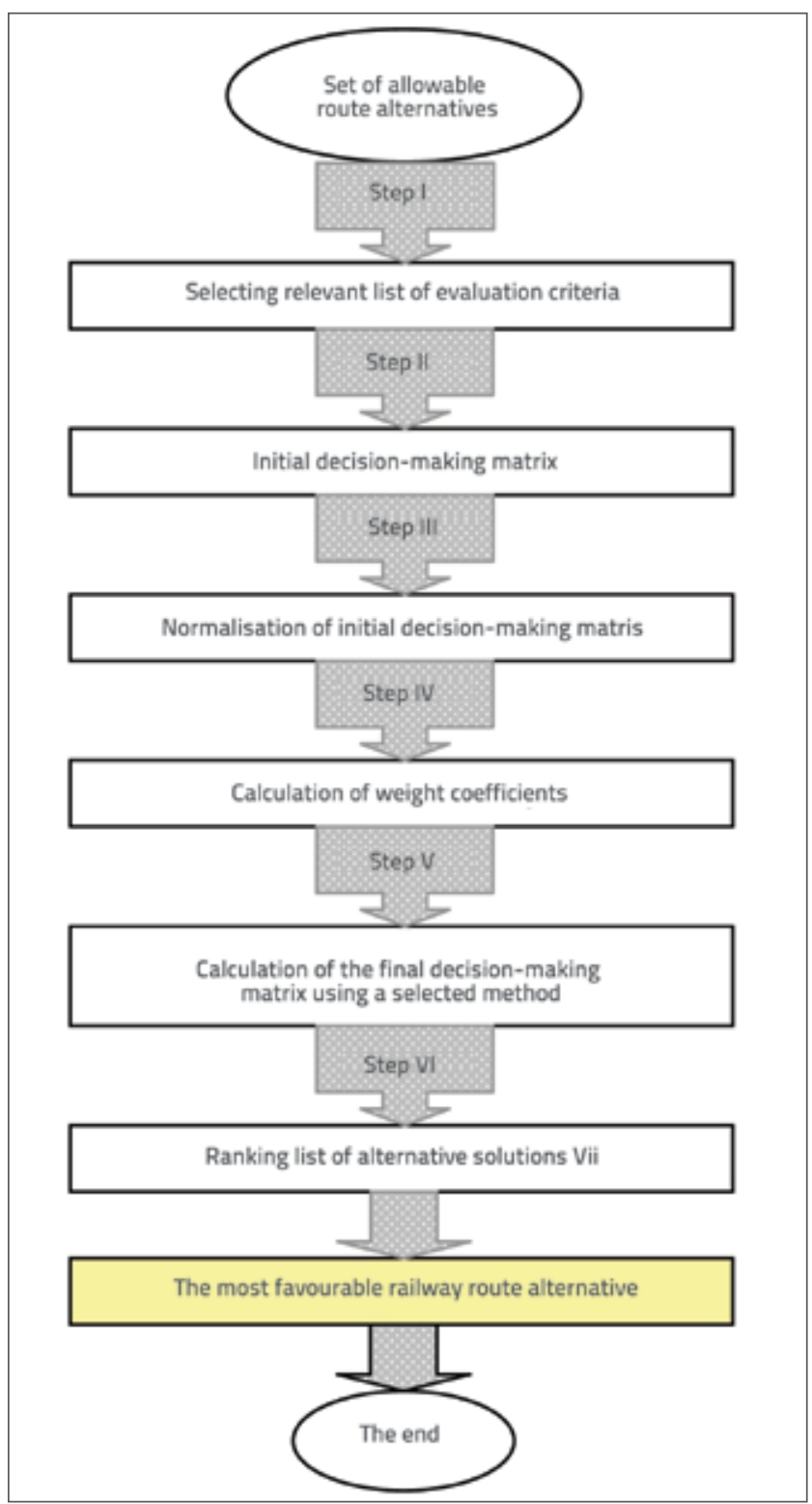

Figure 2. Methodology for decision-making during selection of railway route alternatives 
The first step in the decision-making process is the selection and adoption of the list of criteria that are relevant for the evaluation of alternative route solutions. The adopted list of criteria $(j=1, \ldots, 5)$ is formed of quantitative-economic criteria, quantitative-technical criteria, and qualitative criteria:

$K_{1}$ - investment needed for railway construction (monetary units)

$\mathrm{K}_{2}$ - railway operation and maintenance costs (monetary units)

$K_{3}$ - railway capacity (number of train pairs or number of trains per each direction)

$K_{4}$ - effects of railway on physical development (points)

$K_{5}$ - effects of railway on living environment (points).

The criterion $K_{1}$ defines railway construction investment and is represented with the function $f_{1}$ :

$f_{1}=\sum I=I_{o p}+I_{s t}+I_{e v}+I_{s s-t k} \quad$ (monetary units)

where:

I - individual investments in stable railway installations

$I_{o p} \quad$ - investment in construction of open railway sections

$I_{\text {st }}^{\text {op }} \quad$ - investment in construction of new train stations or in renovation of existing stations

$\mathrm{I}_{\mathrm{ev}} \quad$ - investment in electric traction installations

$l_{s s-t k}$ - investments for SS and TK devices.

The criterion $K_{2}$ defines railway operation and maintenance costs and is represented with the function $f_{2}$ :

$f_{2}=\sum T=T_{\text {ops }}+T_{\text {oev }}+T_{\text {oss-tk }}+T_{\text {osu }}$ (monetary units)

where:

$T$ - individual value of maintenance costs for stable installations and railway accessories

$T_{\text {ops }}$ - maintenance costs for railway and stations

$T_{\text {oev }}$ - maintenance costs for electrical traction facilities

$T_{\text {oss-tk }}$-maintenance costs for SS (signalling and safety) devices and TK (telecommunication) devices

$T_{\text {osu }}$ - traffic organisation and management costs.

The criterion $K_{3}$ defines capacity of the railway line and is represented with the function $f_{3}$ :

$f_{3}=N=\frac{T}{l_{s l}+t_{r}+t_{d}}=\frac{T}{1,67 I_{s l}+0,25 a} \quad$ (numbers of train)

where:

$N$ - capacity of the railway line

$T$ - time for which capacity is calculated

$l_{s l} \quad$ - mean value of minimum interval between successive trains at a reference section

$t_{r}$ - spare time

$t_{d}$ - additional time

a - number of station intervals at a section under study.

The presented relation of the function $f_{3}$ is used for calculating capacity of railway lines using the UIC 406 method.
The criterion $K_{4}$ defines effects the railway will have on physical development and is represented with the function $f_{4}$ :

$f_{4}=\sum P=P_{o p c}+P_{z p}+P_{k i p n}$ (points)

where:

$P \quad$ - individual value of effects the railway will have on physical development

$P_{o p c}$ - preservation of current land uses (habitation, economic activity, rest and recreation

$P_{o p c}$ - occupation of space (agricultural and buildable land)

$P_{\text {kipn }}^{\text {opc }}$ - preservation of cultural/historic and natural heritage (cultural mouniments, national parks and landscape).

Individual effects $\left(P_{o p c^{\prime}} P_{o p c}\right.$ i $\left.P_{k i p n}\right)$ are evaluated and assessed by attributing descriptive grades to all parameters that define these effects. Descriptive grades are most often expressed as follows: favourable, conditionally favourable and unfavourable, and then they are converted into points ranging from 1 to 10 .

The criterion $K_{5}$ defines the influence of railway on living environment and is represented with the function $f_{5}$ :

$f_{5}=\sum U=U_{b-v}+U_{z}+U_{v}+U_{f f}+U_{k m k} \quad$ (points)

where:

$U$ - individual value of railway influence on living environment

$U_{b-v}$ - impact generated by traffic noise and vibrations

$U_{z} \quad$ - influence of railway on and

$U_{v} \quad$ - influence of railway on water

$U_{f f} \quad$ - influence of railway on flora and fauna

$U_{k m k}$ - influence of railway on climate and microclimate.

These influences are evaluated and assessed by attribution of points ranging from 1 to 5 . The criteria $K_{1}$ and $K_{2}$ are expressed quantitatively (through monetary units), $\mathrm{K}_{3}$ is also expressed quantitatively (through monetary unites, while $K_{4}$ and $K_{5}$ are expressed through qualitative units. The criterial function $f_{3}$ should be maximised, while the remaining criterial functions $f_{1} f_{z^{\prime}} f_{4}$ and $f_{5}$ must be minimized.

In the second step of the decision-making process, each alternative solution is individually evaluated according to each criterion. In this way, the initial decision-making matrix $\left(F_{i j}\right)$ is formed (Table 1$)$.

In the third step of the decision-making process, the initial decision-making matrix is normalised, i.e. the criterial functions $f_{i j}$ are normalized to take into account different measurement units, using relations defined in the scope of the method that will be used in decision-making.

In the fourth step the weight coefficients $w_{i}(i=1,2, \ldots, 5)$ of selected criteria are calculated. These coefficients define 
relative significance of each criterion in the formed order of criteria. Normalised values of weight coefficients can be applied and, in such a case, the following relation is applied $w_{i} \geq 0, \sum w_{i}=1$. However, non-normalised values, expressed as whole numbers or percentages, can also be used. Various methods can be used to define weight coefficients: Delfi method, preference structure simulation, entropy method, eigenvector method, etc., while grades from the Saati scale $[22,23]$ can be used for initial significance of criteria.

Weight coefficients can also have several combinations of values, i.e. several scenarios:

- Scenario I: the same weights are attributed to all criteria,

- Scenario 2: greater weights are attributed to economic criteria,

- Scenario 3: greater weights are attributed to traffic/ transport criteria,

- Scenario 4: greater weights are attributed to space-related and environmental criteria,

This combination of weight coefficient values or scenarios is defined so as to cover several typical preference structures of the decision maker, and also to determine the level of stability of the final solution.

In the fifth step the final decision-making matrix is calculated based on the relation defined in the scope of the method selected for multicriteria decision making.

The final sixth step of the decision-making process involves ranking aimed at obtaining the ranking list or the order of precedence of alternative solutions. If there are several weight combinations, or several scenarios, then an appropriate ranking list is established for each scenario. Ranking lists of route alternatives are then used in the final decision-making, i.e. in making the final decision about selection of either a single alternative solution (as final solution) or several alternative solutions (the set of possible solutions is short-listed). The final result of the multicriteria decision-making process is the selection of the most favourable railway route solution.

\subsection{Classification of multicriteria decision-making methods}

Many methods have been developed for the resolution of multicriteria problems, and their classification is given in various publications $[4,7,20]$. Considering the nature of information relating to problems, the MCDM (multicriteria decision-making) methods can be classified as follows:

1. Multi-attribute decision making or recently better known as multicriteria analysis. This group of methods resolves multicriteria problems through selection of the best alternative from the set of previously defined alternative solutions.

2. Multi-objective decision making. This group of methods resolves multicriteria problems by programming the best possible alternative solution.
The multi-attribute decision making methods, i.e. the multicriteria analyses, will be used as support in complex decision making processes. One of such cases is decision making for railway route planning and design, due to discrete nature of railway systems. Several methods from this group belong to the "higher rank methods" and they can be classified as follows

1. compromise-based methods: TOPSIS (technique for order preference by similarity to ideal solution), CP (compromise programming), and VIKOR (multicriteria compromise ranking),

2. usefulness methods: additive method (SWA - simple additive weighting), analytic hierarchical process (AHP - analytic hierarchy process), and methods based on the fuzzy set theory and theory of games,

3. Qutranking methods: ELECTRA I, II, III, IV (elimination and (Et) choice translating reality) PROMETHEE I, II, III, IV (preference ranking organization method of enrichment evaluations).

As in the route planning process a choice must be made between several solutions, in the presence of a number of criteria and different measurement units, the first group of methods from the above classification was adopted for further consideration. After having examined properties of the methods presented in the mentioned group, the decision was made to use the VIKOR method $[16,17,18,19]$ for the selection of the most favourable railway route.

\subsection{Properties of the VIKOR method}

The program package VIKOR, based on compromise programming, has been developed for the multicriteria ranking of alternative solutions. This method focuses on the ranking and selection of alternatives in the presence of conflicting criteria and, at that, the ideal point is used as the reference point in the area covered by criterial functions. However, an alternative that would meet all criteria at the same time does not exist and, therefore, an allowable solution closest to the ideal is sought within the range of criterial functions. The solution closest to the ideal one is called the compromise solution, based on distance measurements adopted. The distance from the ideal point is measured using "limit" metrics $L_{p}$ from the compromise programming method, namely the measurements $S_{j}$ i $R_{j}$;

$S_{j}=\frac{\sum w_{i}\left(f_{i}^{*}-f_{i j}\right)}{\left(f_{i}^{*}-f_{i}^{-}\right)}$

$R_{j}=\max \frac{w_{i}\left(f_{i}^{*}-f_{i j}\right)}{\left(f_{i}^{*}-f_{i}^{-}\right)}$

where:

$f_{i j} \quad$ - value of the $i$-th criterial function of the $j$-th alternative solution $i=1, \ldots, \mathrm{n} \mathrm{i} j=1, \ldots, \mathrm{m}$

$f_{i}^{*} \quad-\max f_{i j}$ and $f_{i}^{-}=\min f_{i, j^{\prime}}$ if the $i$-th criterial function shows profit, and 
$f_{i}^{*} \quad-\min f_{i j}$ and $f_{i}^{-}=\max \mathrm{f}_{\mathrm{ij}}$ if the $i$-th criterial function shows cost; $w_{i} \geq 0$ are weight coefficients of selected criteria.

Ranking by means of $S_{j}$ i $R_{j}$ measurements enables definition of places $s(V)$ i $r(V)$ on the ranking list for the alternatives $V_{j} j=1, \ldots, m$. Ranking lists obtained in this way differ from one another, and so efforts were made to find an additional procedure for defining a single unified ranking list. This ranking list is obtained based on the $Q_{j}$ measurement:

$Q_{j}=v Q S_{j}+(1-v) Q R_{j}, \quad j=1, \ldots, \mathrm{m}$

where:

$$
Q S_{j}=\frac{S_{j}-S^{*}}{S^{-}-S^{*}} \text { i } Q R_{j}=\frac{R_{j}-R^{*}}{R^{-}-R^{*}} ;
$$

$S^{*}=\min S_{j}, S^{-}=\max S_{j}$,

$R^{*}=\min R_{j}, \mathrm{R}^{-}=\max R_{j} ;$

$v$ - weight of the decision making strategy "according to most criteria", and values range within the interval $(0$, 0,5 , and 1).

From the multicriteria standpoint the alternative $V_{j}$ is better that the $V_{k}$ if ranked according to $Q_{1}$ if $Q_{j}<Q_{\mu}$ and it has a higher position on the ranking list. The position on the $\mathrm{Q}$ list is obtained by connecting positions on the lists $Q R$ and $Q S$. The ranking is operated by sorting alternatives according to measurements $Q S, Q R$ and $Q$. The best alternative is the one with the lowest measurement, and it assumes the first place on the ranking list. The measurement $Q$ is the linear function of the weight of the strategy "according to most criteria" $v$, and so the position on the list Q "linear combination" is the position on lists $Q S$ and $Q R$. The stability of position of alternatives on the ranking list is analyzed by changing the value of weight coefficients. According to the VIKOR method, the best alternative from the multicriteria standpoint is the alternative (for the adopted value $w$ ) which is at the first position of the compromise ranking-list for $v=0.5$ but only if it has:

- "sufficient advantage" over the alternative from the next position (condition U1),

- "sufficiently stable" position with the change of weight $v$ (condition U2).

The difference between the measurements $Q_{j}$ for $v=0.5$ is used for the evaluation of "advantage". The alternative $V$ ' has a sufficient advantage over the next $V^{\prime \prime}$ from the ranking list if:

$Q\left(V^{\prime \prime}\right)-Q\left(V^{\prime}\right) \geq D Q$

where $D Q$ is the "advantage threshold" that is defined with respect to theoretical values $Q, Q_{\max }-Q_{\min }=1-0$, and the number of alternatives $\mathrm{m}$ :

$D Q=\min \left(0,25 ; \frac{1}{m-1}\right)$
The threshold is limited with 0.25 for cases with a small number of alternatives.

The condition "sufficient advantage" enables the decision maker to see all alternatives that are "close" from the multicriteria standpoint. It would not be appropriate to present to the decision maker only the alternative from the first position on the ranking list according to $Q$ and to neglect alternatives with "close" values according to Q. The first alternative on the ranking list has a "sufficiently stable" position if it meets at least one of the following conditions:

- it holds the first position on the ranking list according to $Q$ for $\mathrm{V}=0.25$ and $\mathrm{v}=0.75$,

- it holds the first position on the ranking list according to QS,

- it holds the first position on the ranking list according to QR.

If the first alternative from the compromise ranking list does not meet both conditions $U 1$ and $U 2$, it is not considered to be sufficiently better than the alternative holding the second position. In such cases, the VIKOR method is used to form a set of compromise solutions, which contains both the first alternative and the alternative immediately behind it. If the first alternative does not meet only the condition $U 2$, then only the second alternative from the compromise list enters the set of compromise solutions. However, if it does not meet only the condition $\mathrm{U} 1$ then the set of compromise solutions contains alternatives from the compromise ranking list $V^{\prime} i V^{2}$, $\ldots, V^{(K)}$ for which $Q\left(V^{(K)}\right)-Q\left(V^{\prime}\right)<D Q$

\section{Selection of an optimum railway route alternative using the proposed multicriteria decision-making methodology}

Railways are complex infrastructure facilities and their construction or upgrading requires considerable investments. On the other hand, the application of modern concepts of transport system development, and long term planning of improvements in railway sector, call for the implementation of latest structural improvements and modern technological solutions. Having all this in mind, it is very important to select highly rational solutions in the process of design and evaluation of railway route alternatives. At that, the solutions adopted have to guarantee high quality standards in line with modern transport infrastructure developments.

The design of the double track railway line between Indija and Novi Sad is analyzed in this paper. This railway section is situated in the part of the Corridor $\mathbf{X}$ passing through the Republic of Serbia [8].

\subsection{Generation and evaluation of alternative route solutions}

Considering the geographical disposition of the area (existing communities, Fruška gora National Park, and the Danube River) and local geological indicators, four new alternative 
solutions for the railway route have ben envisaged $V_{j}(j=1, \ldots$, 4). Three solutions are on the right bank of the Danube River, while the fourth one is on the left side of this river. Basic properties of these solutions are:

- Alternative $\mathbf{V}_{1}$ - Cortanovci -follows the existing railway line from Indija to Beška and turns toward higher foothills of Fruška gora, and then descends to Sremski Karlovci and Petrovaradin, crosses the new Danube bridge and enters the Novi Sad station. This section is $32,455 \mathrm{~m}$ in length, while the total length of tunnels and bridges is $7,735 \mathrm{~m}$.

- Alternative $\mathbf{V}_{2}$ - Maradik - right after the Indija station the route abandons the corridor of the existing railway and turns toward Maradik, and then descends toward Petrovaradin, crossing the Fruška gora foothills by three tunnels. The entrance to the Novi Sad station is the same as in the Cortanovci alternative. This section is $32,010 \mathrm{~m}$ in length, while the total length of tunnels and bridges is $8430 \mathrm{~m}$.

- Alternative $\mathrm{V}_{3}$-Combined-from Inđija station to Čortanovci station the route of this alternative is the same as that mentioned for the Čortanovci alternative; the route then turns left towards the Fruška gora foothills and joins, at Sremski Karlovci the route set for the Maradik alternative. This section is $32,605 \mathrm{~m}$ in length, while the total length of tunnels and bridges is $9440 \mathrm{~m}$.

- Alternative $\mathbf{V}_{\mathbf{4}}$ - Kovilj - this route leaves the existing railway corridor in front of Beška, turns to the right, descends via a tunnel and crosses the Danube; from there the route follows the Belgrade - Subotica corridor, crosses the Danube - Tisa - Danube Canal, and enters the Novi Sad station. This section is $39,800 \mathrm{~m}$ in length, while the total length of tunnels and bridges is $5160 \mathrm{~m}$.

The above mentioned alternative route solutions $V_{j}(j=1, \ldots$, 4) were evaluated and assessed in accordance with criteria adopted in section 3.1, as follows:

1. The values of criterial functions $f_{1}$ and $f_{2}$ were obtained by summing up relevant individual parameters taken over from the design documentation of the routes under study.

2. The values of the criterial function $f_{3}$ were obtained through simulation analyses conducted for the routes under study, based on the same predefined conditions. In the course of this analysis, the following individual transport/technological parameters were modified: total number and structure of trains, transport organization, and train speed.

3. The values of the criterial function $f_{4}$ were obtained by summing up all individual parameters that define each influence $\left(P_{o p c^{\prime}} P_{z p} i P_{k i p n}\right)$. These parameters are: housing, economic activities, rest and recreation, agricultural and buildable land, cultural monuments, nature reserves and natural landscapes. They were defined for each of the above alternative solutions by statistical processing of survey data obtained through ratings given by experts for a given area. These grades are not only descriptive (favourable, conditionally favourable, and unfavourable) but also numerical (points from 1 to 10 were attributed).

4. The values of the criterial function $f_{4}$ were obtained by summing up all influences exerted on our living environment Here also, the values of these influences were defined by statistical processing of survey data obtained through ratings given by experts for a given area. These ratings were numerical only (points from 1 to 5 were attributed).

Survey data were also analysed by authors of the design documentation, and by several independent experts, including some of the authors of this paper. Calculated values of criterial functions $f_{i j}$, for the criteria $K i(j=1, \ldots, 5)$, as used for evaluating alternative railway route solutions, are presented in Table 2. In this way, the initial decision making matrix $\left(F_{i j}\right)$ was established.

Table 2. Initial decision-making matrix

\begin{tabular}{|c|c|c|c|c|c|}
\hline \multirow{2}{*}{ Alternatives } & $\begin{array}{c}\mathrm{K}_{1} \\
\text { (mil.\$) }\end{array}$ & $\begin{array}{c}\mathrm{K}_{2} \\
\text { (mil.\$/god) }\end{array}$ & $\begin{array}{c}\mathrm{K}_{3} \\
\text { (number } \\
\text { of trains) }\end{array}$ & $\begin{array}{c}\mathrm{K}_{4} \\
\text { (points) }\end{array}$ & $\begin{array}{c}\mathrm{K}_{5} \\
\text { (points) }\end{array}$ \\
\cline { 2 - 7 } & $\min$ & $\min$ & $\max$ & $\min$ & $\mathrm{min}$ \\
\hline $\mathrm{V}_{1}$ & 212,12 & 20,2 & 106 & 35 & 18 \\
$\mathrm{~V}_{2}$ & 223,05 & 19,6 & 107 & 36 & 12 \\
$\mathrm{~V}_{3}$ & 250,05 & 19,8 & 106 & 30 & 11 \\
$\mathrm{~V}_{4}$ & 229,88 & 23,6 & 103 & 44 & 8 \\
\hline
\end{tabular}

It can be seen from the data given in Table 2 that no single alternative can be found in which all criterial function values would be the best. For that reason, and because different measurement units were used in criterial functions, the initial decision making matrix $\left(F_{i j}\right)$ was normalised using the relation (12) and the corresponding results are shown in Table 3. The transformation is made by division with the length of the perimeter (value interval length) of the criterial function. The perimeter length for the i-th criterial function is $D_{i}=f_{i}^{*}$ - $f_{i}^{-}$, where for each i-th criterion $f_{i}^{*}$ corresponds to the best alternative in the system, while $f_{i}^{-}$corresponds to the worst alternative.

$d_{i j}=T\left(f_{i}^{*}-f_{i j}\right)=\frac{f_{i}^{*}-f_{i j}}{D_{i}}, \quad i=1, \ldots, n, \quad j=1, \ldots, m$

The multicriteria decision making activity continues by assigning relative weights to all criteria, i.e. weight coefficients defining importance of these criteria. Just like in the evaluation of criterial functions $f_{4}$ and $f_{5^{\prime}}$ these values were 
Table 3. Normalisation of the initial decision-making matrix

\begin{tabular}{|c|c|c|c|c|c|}
\hline \multirow{2}{*}{ Alternatives } & $\begin{array}{c}\mathrm{K}_{1} \\
\text { (mil. \$) }\end{array}$ & $\begin{array}{c}\mathrm{K}_{2} \\
\text { (mil. \$/god) }\end{array}$ & $\begin{array}{c}\mathrm{K}_{3} \\
\text { (number } \\
\text { of trains) }\end{array}$ & $\begin{array}{c}\mathrm{K}_{4} \\
\text { (points) }\end{array}$ & $\begin{array}{c}\mathrm{K}_{5} \\
\text { (points) }\end{array}$ \\
\cline { 2 - 7 } & $\min$ & $\min$ & $\max$ & $\min$ & $\min$ \\
\hline$V_{1}$ & 0 & 0,15 & 0,25 & 0,36 & 1 \\
$V_{2}$ & 0,29 & 0 & 0 & 0,43 & 0,40 \\
\hline$V_{3}$ & 1 & 0,05 & 0,25 & 0 & 0,30 \\
\hline$V_{4}$ & 0,47 & 1 & 1 & 1 & 0 \\
\hline$f_{i}^{*}$ & 212,12 & 19,6 & 107 & 30 & 8 \\
\hline$f_{i}^{-}$ & 250,05 & 23,6 & 103 & 44 & 18 \\
\hline$D_{i}$ & $-37,93$ & -4 & 4 & -14 & -10 \\
\hline
\end{tabular}

determined based on analysis of survey data, while relative weights were rated only numerically, in the range from 1 to 3. The experts from various fields (design, environmental protection, economics, town planning, and transport) were included in the analysis of survey results. These experts were the authors of the design documentation and several outside experts, including inter alia some of the authors of this paper. After statistical processing of survey results and weight

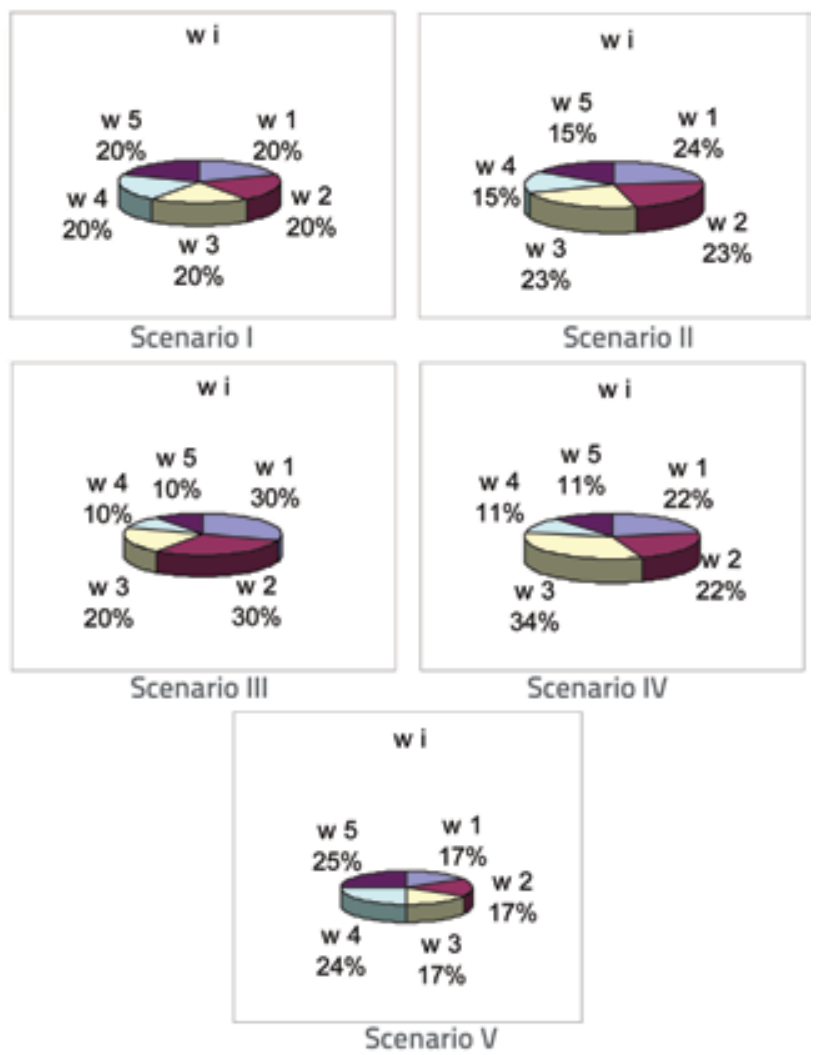

Figure 3. Diagram showing non-normalised weight coefficient values for proposed scenarios coefficients for all criteria, the following five scenarios were proposed:

- Scenario I: all criteria are of the same importance, and so their weight coefficients are the same,

- Scenario II: an advantage is given to economic and transport-related aspects, and so the highest weight coefficient values were assigned to criteria $K_{1^{\prime}} K_{2}$ and $K_{3^{\prime}}$ while the lowest ones were assigned to the criteria $K_{4}$ and $\mathrm{K}_{5^{\prime}}$

- Scenario III: an advantage is given to the economic aspect, and so the highest weight coefficient values were assigned to criteria $\mathrm{K}_{1}$ and $\mathrm{K}_{2}$, while the lowest ones were assigned to the criteria $\mathrm{K}_{4}$ and $\mathrm{K}_{5^{\prime}}$

- Scenario IV: an advantage is given to the transport aspect, and so the highest weight coefficient values were assigned to criterion $\mathrm{K}_{3^{\prime}}$ while the lowest ones were assigned to the criteria $\mathrm{K}_{4}$ and $\mathrm{K}_{5}$,

- Scenario V: an advantage is given to the environmental protection aspect, and so the highest weight coefficient values were assigned to criteria $\mathrm{K}_{4}$ and $\mathrm{K}_{5^{\prime}}$ while the lowest ones were assigned to the criteria $\mathrm{K}_{1^{\prime}} \mathrm{K}_{2}$ and $\mathrm{K}_{3^{\prime}}$

Non-normalised weight coefficient values for the proposed scenarios are given in Table 4 and Figure 3.

Table 4. Non-normalised weight coefficient values for proposed scenarios

\begin{tabular}{|c|c|c|c|c|c|}
\hline \multirow{2}{*}{$\begin{array}{c}\text { Weight } \\
\text { coefficients }\end{array}$} & \multicolumn{5}{|c|}{ Scenarios } \\
\cline { 2 - 6 } & SC I & SC II & SC III & SC IV & SC V \\
\hline w1 & 1 & 3 & 3 & 2 & 2 \\
\hline w2 & 1 & 3 & 3 & 2 & 2 \\
\hline w3 & 1 & 3 & 2 & 3 & 2 \\
\hline w4 & 1 & 2 & 1 & 1 & 3 \\
\hline w5 & 1 & 2 & 1 & 1 & 3 \\
\hline
\end{tabular}

\subsection{Final decision-making matrix and ranking lists}

The following final decision-making matrix and ranking lists were obtained based on rating according to relevant criteria and weight coefficient scenarios, and based on expressions (7), (8) and (9) from the VIKOR software, and according to weights adopted in the strategy of decision-making "according to most criteria" $v=0.5$ (Tables 5 and 6 ): 
Table 5 Decision-making matrices based on Qj, QSj i QRj

\begin{tabular}{|c|c|c|c|c|c|}
\hline \multirow{2}{*}{ Scenarios } & \multirow{2}{*}{ 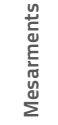 } & \multicolumn{4}{|c|}{ Route alternatives } \\
\hline & & V1 & V2 & V3 & V4 \\
\hline \multirow{3}{*}{ Scenario I. } & Qj & 0,636 & 0 & 0,602 & 1 \\
\hline & QSj & 0,272 & 0 & 0,204 & 1 \\
\hline & QRj & 1 & 0 & 1 & 1 \\
\hline \multirow{3}{*}{ Scenario II. } & Qj & 0,366 & 0 & 0,643 & 1 \\
\hline & QSj & 0,201 & 0 & 0,286 & 1 \\
\hline & QRj & 0,531 & 0 & 1 & 1 \\
\hline \multirow{3}{*}{ Scenario III. } & Qj & 0,084 & 0 & 0,697 & 1 \\
\hline & QSj & 0,107 & 0 & 0,394 & 1 \\
\hline & QRj & 0,061 & 0 & 1 & 1 \\
\hline \multirow{3}{*}{ Scenario IV. } & Qj & 0,177 & 0 & 0,451 & 1 \\
\hline & QSj & 0,181 & 0 & 0,315 & 1 \\
\hline & QRj & 0,174 & 0 & 0,587 & 1 \\
\hline \multirow{3}{*}{ Scenario V. } & Qj & 0,686 & 0 & 0,252 & 1 \\
\hline & QSj & 0,372 & 0 & 0,088 & 1 \\
\hline & QRj & 1 & 0 & 0,415 & 1 \\
\hline
\end{tabular}

Table 6. Ranking list of route alternatives for the proposed scenarios and $v=0.5$

\begin{tabular}{|c|c|c|c|c|c|}
\hline \multirow{2}{*}{ 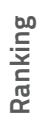 } & \multicolumn{5}{|c|}{ Scenarios } \\
\hline & SC I & SC II & SC III & SC IV & SC V \\
\hline 1 & V2(0) & V2(0) & V2(0) & V2(0) & V2(0) \\
\hline 2 & $\begin{array}{c}\text { V3 } \\
(0,602)\end{array}$ & $\begin{array}{c}V 1 \\
(0,366)\end{array}$ & $\begin{array}{c}\text { V1 } \\
(0,084)\end{array}$ & $\begin{array}{c}V_{1} \\
(0,177)\end{array}$ & $\begin{array}{c}\text { V3 } \\
(0,252)\end{array}$ \\
\hline 3 & $\begin{array}{c}\text { V1 } \\
(0,636)\end{array}$ & $\begin{array}{c}\text { V3 } \\
(0,643)\end{array}$ & $\begin{array}{c}\text { V3 } \\
(0,697)\end{array}$ & $\begin{array}{c}\text { V3 } \\
(0,451)\end{array}$ & $\begin{array}{c}V_{1} \\
(0,686)\end{array}$ \\
\hline 4 & V4 (1) & V4 (1) & V4 (1) & V4 (1) & V4 (1) \\
\hline
\end{tabular}

\subsection{Analysis of results}

The results of the multicriteria ranking based on the VIKOR method (Table 6) show that the alternative V2 (Maradik) is always ranked first, which is why this alternative is proposed as the compromise solution. If an advantage is given to either economic or transport criteria, then we have a set of compromise solutions, and this set is formed of the alternative V2 (Maradik) and alternative V1 (Čortanovci).
Results obtained in this way will provide decision makers with the possibility of choosing the most favourable railway route between the Indija station and the Novi Sad station. Which of the solutions the decision makers will adopt, will depend on the scenario they prefer. If they prefer the scenarios I, II and V then the Maradik alternative is proposed as the compromise solution (the conditions U1 and U2 are fulfilled). If the preferred scenarios are III and IV, then the set of compromise solutions is proposed, namely the Maradik and Čortanovci alternatives (condition $\mathrm{U} 2$ is fulfilled, but the condition U1 remains unfulfilled), and the activity is resumed by making additional analyses and calculations for these solutions only. In the repeated ranking of the two solutions, their respective advantages and deficiencies will be revealed, and the most favourable compromise solution will be selected. This procedure is not presented in this paper.

\section{Conclusion}

The proposed multicriteria decision-making methodology enables an integrated and systematic resolution of problems involving selection of best possible railway routes during the planning and design process, and is hence a valuable asset to final decision makers. According to this methodology, the railway route is evaluated using a number of criterial functions (investments, costs, capacity, effects on physical development, and influences on living environment). Route alternatives are generated using various structural and service-life parameters relevant to the system. Multicriteria analysis methods are used in the alternative solution ranking process. Several scenarios with different weight coefficients enable stability verification for alternative solutions figuring on ranking lists. The final result of the multicriteria decisionmaking is the most favourable route proposal, and this route should be the best one from the set of predefined allowable solutions, taking into account the criteria and realistic limitations adopted in the methodology. The results obtained in the example presented in the paper point to the accuracy and practical applicability of this methodology, and have proven to be a valuable aid and support in decision making. The methodology can successfully be applied for the resolution of problems involving selection of railway routes, and can also be used for other railway infrastructure facilities.

\section{Acknowledgement}

This paper has been prepared with the support of the Ministry of Education and Science of the Republic of Serbia in the scope of the technological project No. 36012: "Study of technical-technological, staffing and organisational capabilities of Serbian Railways from the aspect of current and future EU requirements". 


\section{REFERENCES}

[1] Ballestero, E.; Antón, J. M.; Bielza, C.: Compromise-Based Approach to Road Project Selection in Madrid Metropolitan Area, Journal of the Operations Research Society of Japan, 46(2003)1, 99-122.

[2] Banai, R.: Public Transportation Decision-Making: A Case Analysis of the Memphis Ligt Rail Corridor and Route Selection with Analytic Hierarchy Process, Journal of Public Transportation, 9 (2006) 2, 1-24.

[3] Barić, D.; Radačić, Ž.; Čurepić, D.: Implementation of multicriteria decision-making method in selecting the railway line for reconstruction, ICTS 2006 Transportation Logistics in Science and Practice, Proceedings / Portorož, 2006.

[4] Borović, S.; Nikolić, I.: Višekriterijumska optimizacija: metode, primena u logistici, softver, Centar vojnih škola Vojske Jugoslavije, Beograd, 1996.

[5] Brauers, W. K.; Peldschus, P.; Zavadskas, E. K.; Turskis, Z.: Multi-Objective Optimization of Road Design Alternatives with an Application of the MOORA Method, The 25th International Symposium on Automation and Robotics in Construction, June 2008, 541-548.

[6] Cristóbal, J. R. S. ; Biezma, M. V.; Martínez R.; Somoza, R.: Selection of materials under aggressive environments: The VIKOR method, 3rd International Conference on Integrity, Reliability and Failure, Porto/Portugal, July 2009.

[7] Čupić, E. M.; Rao Tummala, V.T.: Savremeno odlučivanje-Metode i primena, Naučna knjiga, Beograd, 1997.

[8] Studija podobnosti modernizacije železničke pruge SuboticaBeograd-Niš-Dimitrovgrad: Bankarski dosije, Saobraćajni institut CIP, Sofrerail Paris, Beograd, 1991.

[9] Jha, M.; Schonfeld, P.; Samanta, S.: Optimizing Rail Transit Routes with Genetic Algorithms and GIS, Journal of Urban Planning and Development, 133(2007.)3, 161-171.

[10] Kalamaras, G. S.; Brino, L.; Carrieri, G.; Pline, C.; Grasso, P.: Application of Multicriteria Analysis to Select the Best Highway Alignment, Tunelling and Underground Space Technology, 15(2000.)4, 415-420.
[11] Karleuša, B.; Ožanić, N.: Određivanje prioriteta u realizaciji vodnogospodarskih planova, Građevinar 63 (2011.) 2, 151-161.

[12] Kosijer, M.; Ivić, M.: Primena višekriterijumske optimizacije pri izboru optimalnog koridora železničkih pruga, Železnice, 7-9 (1997.), 368-372.

[13] Kosijer, M.: Prilog metodologiji vrednovanja varijanata pruga za velike brzine na nivou generalnog projekta, magistarski rad, Građevinski fakultet, Beograd, 1995.

[14] Margeta, J.; Prskalo, G.: Izbor lokacije za sanitarno odlagalište, Građevinar 58 (2006) 12, 997-1008.

[15] Mladineo, N.; i dr.: Izbor trase jadranske autoceste primjenom metode višekriterijalne analize, Zbornik radova SYM-OP-IS 1990, Kupari, 651-654.

[16] Opricovic, S.: A compromise solution in water resources planing, Water Resour Manage, 23 (2009), 1549-1561.

[17] Opricovic, S.; Tzeng, G-H.: A comparative analysis of the DEA-CCR model and the VIKOR method, Yugoslav Journal of Operational Research, 18 (2008), 87-93.

[18] Opricovic, S.; Tzeng, G-H.: Extended VIKOR method in comparison with outranking methods, European Journal of Operational Research, 178 (2007), 514-529.

[19] Opricovic, S.; Tzeng, G-H.: Compromise solution by MCDM methods: A comparative analysis of VIKOR and TOPSIS, European Journal of Operational Research, 156 (2004), 445-455.

[20] Opricović, S.: Višekriterijumska optimizacija sistema u građevinarstvu, Građevinski fakultet, Beograd, 1998.

[21] Roy, B.; Hugonnard, J. C.: Ranking of Suburban Line Extension Projects on the Paris Metro System by a Multicriteria Method, Transportation Research-A, 16A, 4 (1982), 301-312.

[22] Saaty, T. L.: How to make a decision: The Analytic Hierarchy Process, European Journal of Operational Research, 48 (1990), 9-26.

[23] Saaty, T. L.: Fundamentals of Decision Making and Priority Theory with AHP, Pittsburgh: RWS Publications, 1994. 